Original Contribution

\title{
THE INFLUENCE OF THE SEX AND HEIGHT AT THE WITHERS ON PELVIS SIZE OF DONKEYS IN AUSTRIA
}

\author{
M. Uroševic ${ }^{1 *}$, D. Drobnjak ${ }^{1}$, R. Vlaeva ${ }^{2}$, P. Dameski ${ }^{3}$, G. Stanišic ${ }^{4}$ \\ ${ }^{1}$ Center for Preservation of Indigenous Breeds, Beograd-Zemun, Serbia \\ ${ }^{2}$ Department of Non-ruminant and Other Animals, Faculty of Agriculture, Trakia University, \\ Stara Zagora, Bulgaria \\ ${ }^{3}$ Faculty of Veterinary Medicine, St. Clement of Ohrid, University of Bitola, North Macedonia \\ ${ }^{4}$ High-school for Agriculture, Sabac, Serbia
}

\begin{abstract}
During the recent decades, the donkey, as an ever-employed labour animal, is slowly but steadily losing its value. The agricultural industrialization, mechanization of many processes at the mountain and valley farms led to rejection of the donkeys as a livestock. This reduction in donkey numbers evokes some concerns. This fact is a good reason to study all aspects of these domestic animals, in order to revive their role and to restart their livestock growth in the familiar habitat, and bring them into the new environmental conditions.

For the recent research, 35 donkeys (23 males and 12 females) were chosen. All animals lived on Styria terrain in Austria. The following morphometric parameters were analysed: height at the withers (VG), pelvis length (DK), pelvis width (SK), and point of buttock width (SSK).

For the males, the average height at the withers was $116.70 \mathrm{~cm}$ and the average pelvis length $-40.13 \mathrm{~cm}$. The average pelvis width was $38.56 \mathrm{~cm}$, and the average point of buttock width $-16.39 \mathrm{~cm}$.

For the females the average height at the withers was $101.48 \mathrm{~cm}$, the average pelvis length $-36.00 \mathrm{~cm}$, pelvis width was $35.41 \mathrm{~cm}$. The average point of buttock width was $13.66 \mathrm{~cm}$.

These measurements show the influence of the height at the withers on the development of the pelvis, particularly on its width and height for both males and females. Comparatively to other donkey populations of the world, the Austrian donkey has an average size.
\end{abstract}

Key wards: Donkey, morphological characteristics, correlations

\section{INTRODUCTION}

During the recent decades, the donkey, as an ever-employed labour animal, is slowly but steadily losing its value. The agricultural industrialization, mechanization of many processes at the mountain and valley farms led to the rejection of the donkeys as a livestock. This reduction in donkey numbers evokes some concerns. This fact is a good reason to study all aspects of these domestic animals, in order to revive their role and to restart their livestock growth in the familiar habitat, and to bring them into the new environmental conditions. The domestic donkey (Equus asinus) originate from Africa, where, there are two kinds of donkeys: Nubian and Somali.

\footnotetext{
*Correspondence to: Milivoje Urošević, Center for Preservation of Indigenous Breeds, Republic of Serbia, Belgrade, email: milivoje.urosevic@gmail.com
}

Their enormous almost mystical endurance is well known. There is no place in the world where a donkey is not able to do the most difficult work and transportation. The donkey has an amazing capability of stable movement in the most hard-to-get places.

So far, studies of the exterior characteristics have been performed on several populations in different countries. In Italy, the basic morphological parameters of donkey breed Amiata have been studied in the province of Tuscany (1). In the Adriatic islands, the donkey was the main working animal. The morphological characteristics of donkeys on the Island Mljet have studied almost 60 years ago (2). The Baroque donkey is one of the rarest donkey breeds in the world. The first study on the morphological characteristics of this breed was published in 2019 (3). The external characteristics of donkeys in the 
Kabylie area of Algeria were also reported in research papers (4). Donkey body conformation studies were conducted in northwestern and central Ethiopia (5). In Turkey, studies were conducted on several donkey populations (6-7). The structure of the Littoral Dinaric donkey has been well researched in Croatia (8). Kostukova et al. (9) reported the morphological characteristics of donkeys in the Czech Republic. The Italian Romanoglo donkey is a breed, which belongs to a big donkey group. The morphological characteristics of donkeys of this breed were studied in details (10). Turkish scientist (11) reported the morphological features of Hasavi donkey, an indigenous donkey breed in Saudi Arabia, in the eastern province. The exterior of a domestic donkey in south eastern Serbia was studied also well studied (12).

The aim of the present study was to estimate the morphological characteristics of donkeys bred in Austria, and to determine the influence of sex and height at the withers on pelvis size.

\section{MATERIAL AND METHODS}

For the examination, 35 donkeys (23 males and 12 females) were chosen. These animals lived in Austria, on terrain in Styria district.

The following morphometric parameters were analysed: height at the withers (VG), pelvis length (DK), pelvis width (SK), and point of buttock width (SSK). The measurements were taken with Litin stick and Vernier calliper. The measurement points were as follow: for the height at the withers - the vertical line from
UROŠEVIĆ M., et al. the ground up through the point above the elbow joint and further up to the highest point of the withers, which are made by cranial line of the scapular cartilage and transversal extension of the first dorsal vertebras; pelvis length - from the front edge of the femur to the rear edge of the point of buttock; pelvis width - the distance between left and right protrusion points of the femur; point of buttock width the distance between the left and right points of buttock.

The measured data was first processed by the descriptive statistics method with the values distribution frequency by gender. Pearson method gave the data correlation by gender, whereas the correlation between the statistics values of the measured parameters of two genders was made by t-test. All the data were processed by Statistical Package for the Social Sciences (SPSS) for Windows Release 17.0.0.

\section{RESULTS}

In Table 1, are presented the results from the descriptive statistics for the male donkeys included in the study. The average height at the withers of the males was $116.70 \mathrm{~cm}$ with variation interval from 99.60 to $140.60 \mathrm{~cm}$. The male pelvis length was on average 40.13 $\mathrm{cm}$ with minimal and maximal values of 35.00 $\mathrm{cm}$ and $50.00 \mathrm{~cm}$. The average pelvis height was $38.56 \mathrm{~cm}$, and the average point of buttock width was $16.39 \mathrm{~cm}$.

The frequency of distribution of the examined parameters for the group of studied male donkeys is presented in Figure 1.

Table 1. The descriptive statistics values of males $(n=23)$

\begin{tabular}{|l|l|l|l|l|}
\hline Parameter $(\mathrm{cm})$ & VG & DK & SK & SSK \\
\hline Mean & 116.70 & 40.13 & 38.56 & 16.39 \\
\hline Std. Error of Mean & 2.57 & 0.92 & 1.14 & 0.51 \\
\hline Std. Deviation & 12.35 & 4.42 & 5.47 & 2.46 \\
\hline Minimum & 99.60 & 35.00 & 32.00 & 12.00 \\
\hline Maximum & 140.60 & 50.00 & 51.00 & 23.00 \\
\hline
\end{tabular}

When the Pearson correlation is applied, a very considerable and significant correlation between all the male parameters was registered (Table 2). For males, considerable positive correlation was observed between the height at the withers and pelvis length -0.851 , between the height at the withers and pelvis width -
0.937, between pelvis length and point of buttock width -0.617 , and between pelvis width and point of buttock width -0.637 . In addition, a major positive correlation for males was observed between the height at the withers and point of buttock width -0.466 . 


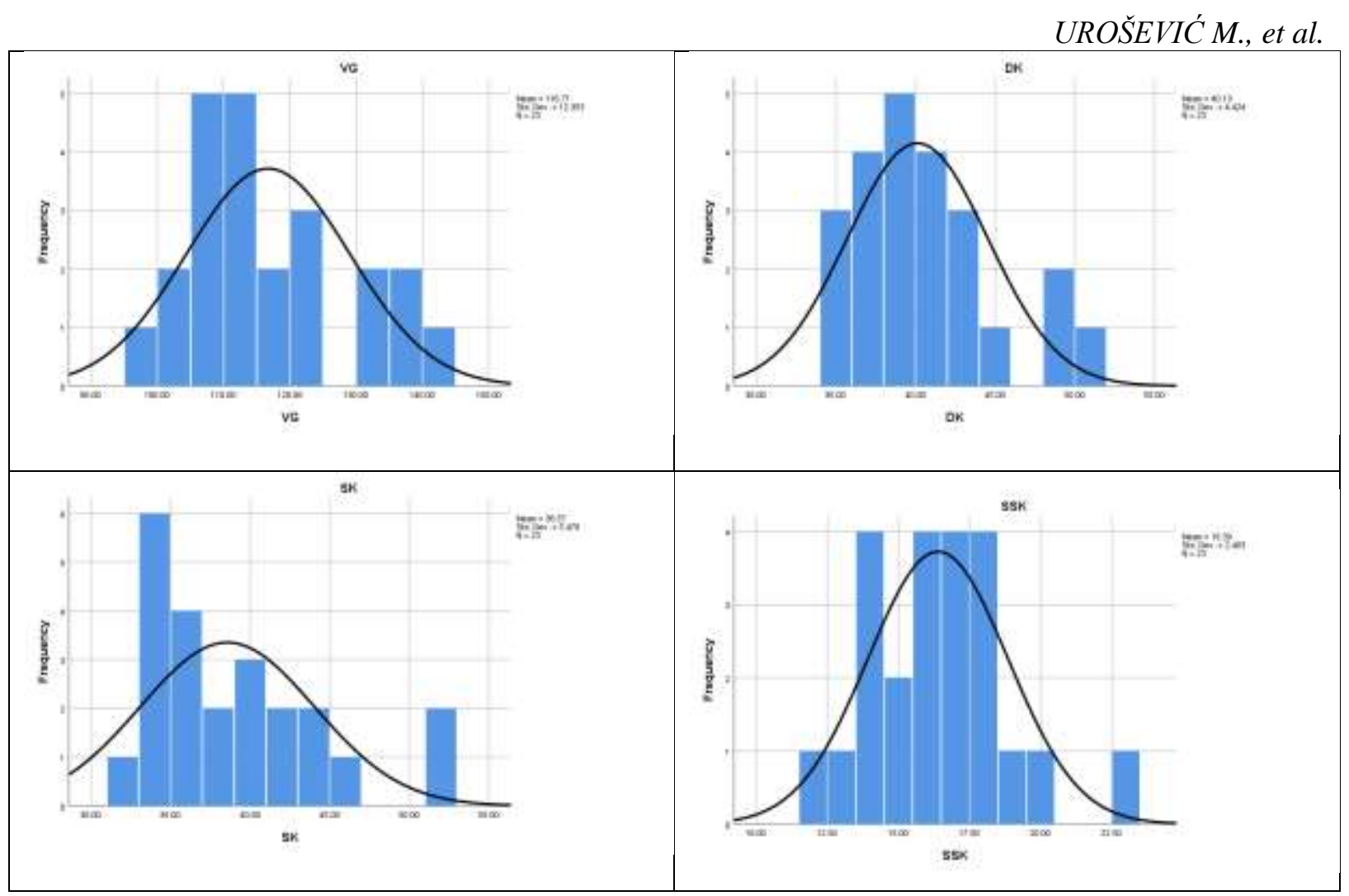

Figure 1. Frequency of distribution of measured parameters for the males

Table 2. Pearson correlation values for males

\begin{tabular}{|c|c|c|c|c|c|}
\hline \multicolumn{2}{|c|}{ Parameter } & VG & DK & SK & SSK \\
\hline \multirow{3}{*}{$\mathrm{VG}$} & Pearson Correlation & 1 & $0.851^{* *}$ & $0.873^{* * *}$ & $0.466^{*}$ \\
\hline & Sig. (2-tailed) & & 0.000 & 0.000 & 0.025 \\
\hline & $\mathrm{N}$ & 23 & 23 & 23 & 23 \\
\hline \multirow{3}{*}{ DK } & Pearson Correlation & $0.851^{*: 2}$ & 1 & $0.937^{* *}$ & $0.617^{* *}$ \\
\hline & Sig. (2-tailed) & 0.000 & & 0.000 & 0.002 \\
\hline & $\mathrm{N}$ & 23 & 23 & 23 & 23 \\
\hline \multirow{3}{*}{ SK } & Pearson Correlation & $0.873^{* ;}$ & $0.937^{* *}$ & 1 & $0.637^{* *}$ \\
\hline & Sig. (2-tailed) & 0.000 & 0.000 & & 0.001 \\
\hline & $\mathrm{N}$ & 23 & 23 & 23 & 23 \\
\hline \multirow{3}{*}{ SSK } & Pearson Correlation & $0.466^{*}$ & $0.617^{* *}$ & $0.637^{* * *}$ & 1 \\
\hline & Sig. (2-tailed) & 0.025 & 0.002 & 0.001 & \\
\hline & $\mathrm{N}$ & 23 & 23 & 23 & 23 \\
\hline
\end{tabular}

**. Correlation is significant at the 0.01 level (2-tailed).

*. Correlation is significant at the 0.05 level (2-tailed).

It Table 3, are presented the results for the studied group of female donkeys. The average height at the withers was $101.48 \mathrm{~cm}$, with a standard deviation of 9.23 and variation interval from 90.50 to $125.70 \mathrm{~cm}$. The average pelvis length was $36.00 \mathrm{~cm}$ with standard deviation of $3.74 \mathrm{~cm}$. The variation interval for pelvis width was from 31.00 to $42.00 \mathrm{~cm}$ with an average mean $35.41 \mathrm{~cm}$. The point of buttock width for females was on average $13.66 \mathrm{~cm}$ with a standard deviation of $2.80 \mathrm{~cm}$.

Table 3. The descriptive statistics values for females $(n=12)$

\begin{tabular}{|l|l|l|l|l|}
\hline Parameter $(\mathrm{cm})$ & VG & DK & SK & SSK \\
\hline Mean & 101.48 & 36.00 & 35.41 & 13.66 \\
\hline Std. Error of Mean & 2.66 & 1.08 & 1.09 & 0.81 \\
\hline Std. Deviation & 9.23 & 3.74 & 3.77 & 2.80 \\
\hline Minimum & 90.50 & 31.00 & 31.00 & 9.00 \\
\hline Maximum & 125.70 & 44.00 & 42.00 & 18.00 \\
\hline
\end{tabular}


Figure 2, represents the frequency of distribution of the examined parameters for the group of studied female donkeys.

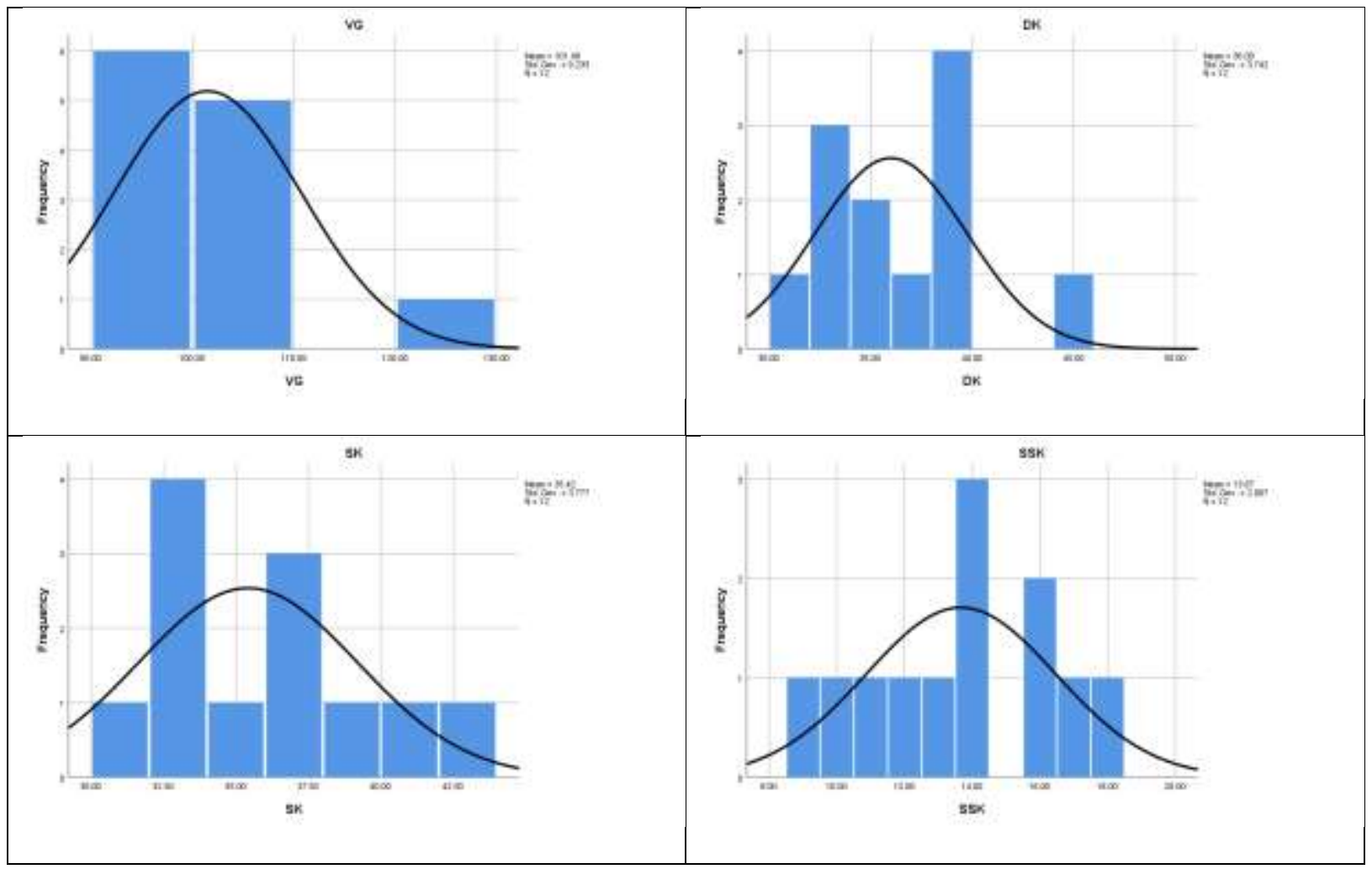

Figure 2. Frequency of distribution of measured parameters for the females

The Pearson correlation for females, presented in Table 4, demonstrated a significant positive correlation between the height at the withers and pelvis length and width, than correlation between pelvis length and pelvis width.

Table 4. Pearson correlation values for females

\begin{tabular}{|l|l|l|l|l|l|}
\hline \multirow{2}{*}{ Parameter } & VG & DK & SK & SSK \\
\hline \multirow{4}{*}{ VG } & Pearson Correlation & 1 & $0.879^{* *}$ & $0.787^{* *}$ & 0.491 \\
\cline { 2 - 6 } & Sig. (2-tailed) & & 12 & 0.000 & 0.105 \\
\cline { 2 - 6 } & $\mathrm{N}$ & 12 & 12 & 12 & 12 \\
\hline \multirow{3}{*}{ DK } & Pearson Correlation & $0.879^{* *}$ & 1 & $0.849^{* *}$ & 0.312 \\
\cline { 2 - 6 } & Sig. (2-tailed) & 0.000 & & 0.000 & 0.324 \\
\cline { 2 - 6 } & $\mathrm{N}$ & 12 & 12 & 12 & 12 \\
\hline \multirow{3}{*}{ SK } & Pearson Correlation & $0.787^{* *}$ & $0.849^{* *}$ & 1 & 0.400 \\
\cline { 2 - 6 } & Sig. (2-tailed) & 0.002 & 0.000 & 12 & 0.197 \\
\cline { 2 - 6 } & $\mathrm{N}$ & 12 & 12 & 12 & 12 \\
\hline \multirow{3}{*}{ SSK } & Pearson Correlation & 0.491 & 0.312 & 0.400 & 12 \\
\cline { 2 - 6 } & Sig. (2-tailed) & 0.105 & 0.324 & 0.197 & \\
\cline { 2 - 6 } & $\mathrm{N}$ & 12 & 12 & 12 & 12 \\
\hline
\end{tabular}

**. Correlation is significant at the 0.01 level (2-tailed).

The correlation between the height at the withers and pelvis length was 0.879, and between the height at the withers and pelvis width - 0.787. We also estimated a positive correlation for females between pelvis length and pelvis width -0.849 .
Any significant positive or negative correlation between the point of buttock width and other parameters for females was not noticed.

It is evident that there is a statistical discrepancy $(\mathrm{P}<0.05)$ between the height at the 
withers, point of buttock width and length, of males and females, whereas no statistical discrepancy was noticed for pelvis width between both genders.

The imparities between the examined exterior measurements for male and female donkeys

\section{UROŠEVIĆ M., et al.}

are presented in Table 5. The mean paired differences for height at withers is $19.00 \mathrm{~cm}$, for the pelvis length $-5.58 \mathrm{~cm}$, for pelvis height $-4.50 \mathrm{~cm}$ and for the point of buttock width $3.33 \mathrm{~cm}$. As expected, all the values are in favor of male donkeys.

Table 5. Statistics of measured parameters for males and females

\begin{tabular}{|c|c|c|c|c|c|c|c|c|}
\hline & \multicolumn{5}{|c|}{ Paired Differences } & \multirow{3}{*}{$\mathrm{t}$} & \multirow{3}{*}{ df } & \multirow{3}{*}{ Sig. (2-tailed) } \\
\hline & \multirow[t]{2}{*}{ Mean } & \multirow[t]{2}{*}{$\begin{array}{l}\text { Std. } \\
\text { Deviation }\end{array}$} & \multirow[t]{2}{*}{$\begin{array}{l}\text { Std. Error } \\
\text { Mean }\end{array}$} & \multicolumn{2}{|c|}{$\begin{array}{l}\text { 95\% Confidence } \\
\text { Interval of the } \\
\text { Difference }\end{array}$} & & & \\
\hline & & & & Lower & Upper & & & \\
\hline $\mathrm{VG}^{\hat{\gamma}}-\mathrm{VG}_{+}$ & 19.00833 & 22.43757 & 6.47717 & 4.75218 & 33.26448 & 2.935 & 11 & $0.014^{*}$ \\
\hline $\mathrm{DK}_{\hat{O}}^{\hat{O}}-\mathrm{DK} \hat{q}$ & 5.58333 & 8.09555 & 2.33698 & 0.43967 & 10.72700 & 2.389 & 11 & $0.036^{*}$ \\
\hline $\mathrm{SK}{ }^{\lambda}-\mathrm{SK}+$ & 4.50000 & 9.01010 & 2.60099 & -1.22474 & 10.22474 & 1.730 & 11 & $0.112^{\mathrm{ns}}$ \\
\hline $\mathrm{SSK}_{0}^{\lambda}-\mathrm{SSK}_{+}$ & 3.33333 & 4.69687 & 1.35587 & 0.34908 & 6.31758 & 2.458 & 11 & $0.032^{*}$ \\
\hline
\end{tabular}

\section{DISCUSSION}

Based on the measurement results, of correlation values, it was considered that the height at the withers influences the pelvis development for both, males and females. This influence first applies to the two parameters pelvis length and pelvis width, whereas the point of buttock width does not much depend on a height at the withers. For the males and females, there is a statistical correlation between the most measured parameters. Having compared the parameters of donkey population in Austria with parameters of the other population in the world, we fixed definite deviation in pelvis growth and development, for some population it is bigger and for the other is less.

Babić measured pelvis length on donkeys in 1939 (13). He defined an average pelvis length for the Apulian male donkeys as $41.8 \mathrm{~cm}$, and the average pelvis width as $37.6 \mathrm{~cm}$. The height at the withers was estimated on average $128.8 \mathrm{~cm}$. The females' average height at the withers was $124.3 \mathrm{~cm}$, pelvis length $-39.7 \mathrm{~cm}$, and pelvis width $-37.7 \mathrm{~cm}$. Those measurements correlate with the ones obtained at our research - male pelvis length of 40.13 $\mathrm{cm}$ and female pelvis length of $36.00 \mathrm{~cm}$. Nevertheless, the average data of height at the withers of Apulian males and females were lower than the Austrian ones. The height at the withers of Austrian male donkeys was $12.1 \mathrm{~cm}$ less than of the Apulian donkeys, and the height at the withers of Austrian females was $22.9 \mathrm{~cm}$ less. Study of the morphological traits of the donkeys on the Mljet Island (Croatia,
Adriatic Sea) was conducted in 1959 (2). By a total number of 183 males, was measured at an average height at the withers of $100.65 \pm 0.34$ $\mathrm{cm}$. The average pelvis length was $33.20 \pm$ $0.11 \mathrm{~cm}$. The total number of the selected females was 292, with an average height at the withers of $99.48 \pm 0.30 \mathrm{~cm}$, and average pelvis length $-32.54 \pm 0.10 \mathrm{~cm}$. These donkeys from Mljet Island were shorter than the ones from Austria, and the pelvis length was smaller too. The pelvis length of the Austrian males was $6.93 \mathrm{~cm}$ bigger; the pelvis length of the Austrian females was $3.46 \mathrm{~cm}$ longer than the length of the females on the Mljet Island.

When studied the exterior of the three donkey types in Croatia, it was discovered that the average height at the withers of the Litoral Dinaric type was $96.93 \mathrm{~cm}$, the North Adriatic type was $115.28 \mathrm{~cm}$, and of the highest Istrian type was $124.07 \mathrm{~cm}$ (7). The average pelvis length of the Littoral Dinaric type was 32.47 $\mathrm{cm}$, of the North Adriatic type was $37.65 \mathrm{~cm}$, and of the Istrian type was $41.01 \mathrm{~cm}$. The average pelvis width of the shortest type of the Littoral Dinaric donkey was $31.59 \mathrm{~cm}$, the North Adriatic $-37.56 \mathrm{~cm}$, and of the Istrian type was $41.45 \mathrm{~cm}$. Comparing these data with the results of our study, we can notice that the Austrian donkey type is the closest in height at the withers to the North Adriatic donkey, whereas Littoral Dinaric type is shorter than the Austrian one, and the Istrian donkey is much higher than the Austrian donkey.

The average height at the withers of Amiata type donkey (1) was $125.82 \pm 5.25$ for males 
and $125.15 \pm 21.0 \mathrm{~cm}$ for females. The average pelvis length for males was $42.18 \pm 3.62 \mathrm{~cm}$, and for females $-40.13 \pm 2.47 \mathrm{~cm}$. The height at the withers and pelvis length of Amiata type were bigger than the ones of the Austrian type donkeys. The average height at the withers reported for male donkeys in the Czech Republic were $109.9 \mathrm{~cm}$, and for females $106.0 \mathrm{~cm}$ (8). The average pelvis length for males was $33.2 \mathrm{~cm}$, and for females was 32.2 $\mathrm{cm}$. Consequently, Czech donkeys are shorter and their pelvis length is less than those of the Austrian donkeys.

When studying the exterior of donkeys in Turkey, Romania and North Macedonia, it was discovered that the average height at the withers of males in Romania was $101.20 \mathrm{~cm}$, in Turkey it was $103.10 \mathrm{~cm}$, and in North Macedonia - $99.70 \mathrm{~cm}$ (6). The biggest pelvis length had donkeys in Turkey $-35.80 \mathrm{~cm}$, then in Romania - $35.60 \mathrm{~cm}$, and the lowest pelvis length was of donkeys in North Macedonia $34.60 \mathrm{~cm}$. The height at the withers of donkeys from these three countries was much lower than the height at the withers of donkeys in Austria. It worth notice, that the pelvis length of females in Turkey and Romania was the same as of those in Austria, whereas the pelvis of females in Macedonia was $2.4 \mathrm{~cm}$ shorter than the pelvis of females in Austria.

The characteristics of Amiata-type donkeys in four regions of Italy were studied by Sargentiniet al. (14). They discovered that the average height at the withers varied from 123.0 $\pm 1.09 \mathrm{~cm}$ to $130.7 \pm 6.9 \mathrm{~cm}$. The group of donkeys with the smallest height at the withers had also the least average pelvis length $-37.7 \pm$ $3.1 \mathrm{~cm}$. The longest pelvis on average was not found in the group of donkeys with the biggest height at the withers but was found in the group with the average height at the withers $125.6 \pm 2.4 \mathrm{~cm}$. The average pelvis length of the Amiata group was $45.1 \pm 2.4 \mathrm{~cm}$. Interesting, the donkeys in the group with the longest pelvis had the widest setting of the point of buttocks $-19.2 \pm 4.3 \mathrm{~cm}$. The smallest width of the point of buttocks was registered in the group with biggest average height at the withers. The average point of buttocks width in that group was $15.1 \pm 2.1 \mathrm{~cm}$. It is remarkable, that the height at the withers values of this group were much higher, than those of the Austrian donkeys. In addition, the pelvis length and point of buttocks width values were also higher than the ones of our study.
UROŠEVIĆ M., et al.

When studying morphological characteristics of the White Baroque donkey in Austria (3), it was discovered that the average height at the withers of males was $115.5 \pm 4.5 \mathrm{~cm}$ with the variation interval from $108.4 \mathrm{~cm}$ to $120.3 \mathrm{~cm}$ and variation coefficient of $3.9 \%$. The pelvis length of males was $38.8 \pm 2.7 \mathrm{~cm}$ with the variation interval from 36.0 to $43.0 \mathrm{~cm}$. The variation coefficient was $7.2 \%$. The average pelvis width was $34.6 \pm 2.7 \mathrm{~cm}$ with the variation interval from 32.0 to $39.0 \mathrm{~cm}$. The variation coefficient was $7.8 \%$. The average point of buttocks width of males was $13.8 \pm$ $1.9 \mathrm{~cm}$. The variation interval was $12.0-17.0$ $\mathrm{cm}$, and the variation coefficient was higher $13.9 \%$. In the same population of the White Baroque donkey in Austria the morphological parameters were studied. It was discovered that the average height at the withers was $112.0 \pm$ $5.7 \mathrm{~cm}$ with the variation interval from 104.2 to $122.2 \mathrm{~cm}$. The female variation coefficient was higher than that of the males and it was $5.1 \%$. The average pelvis length for the females was $40.7 \pm 2.2 \mathrm{~cm}$ with the variation interval from 36.0 to $44.0 \mathrm{~cm}$. The female variation coefficient was lower than that of males and it was $5.5 \%$. The average pelvis width was $39.5 \pm 2.7 \mathrm{~cm}$ with minimum 35.0 $\mathrm{cm}$ and maximum $44.0 \mathrm{~cm}$. The variation coefficient was $6.9 \%$. The average point of buttocks width was $14.6 \pm 2.1 \mathrm{~cm}$ with minimum of $12.0 \mathrm{~cm}$ and maximum of 18.0 $\mathrm{cm}$. The variation coefficient was $14.8 \%$. When White Baroque donkey parameters were compared with those of recent study, it was evident that the height at the withers of male Baroque donkeys was in the same variation interval, as well as the average height at the withers of population in our study. The pelvis of the Baroque male donkeys was shorter than the one of the Austrian type of population we were studying. The values of pelvis width and point of buttock of the Baroque males were lower. The average female height at the withers was a little bit higher than of the Austrian type. The pelvis-measured parameters of Baroque female donkey are higher than those of the Austrian females.

The average height at the withers of males in the population under study was $116.70 \mathrm{~cm}$, and the average pelvis length was $40.13 \mathrm{~cm}$. The average pelvis width was $38.56 \mathrm{~cm}$, and the average point of buttock width was $16.39 \mathrm{~cm}$. The average height at the withers for females was $101.48 \mathrm{~cm}$, the average pelvis length was 36.00 , and the average pelvis width was 13.66 
$\mathrm{cm}$. The obtained data show that the height at the withers influences the pelvis development, and first of all its length and width for both male and female donkeys. The Austrian type of donkey, comparatively to the other types in the world, is of the average size.

\section{CONCLUSION}

The average height at the withers of males in the population under study was $116.70 \mathrm{~cm}$, and the average pelvis length was $40.13 \mathrm{~cm}$. The average pelvis width was $38.56 \mathrm{~cm}$, and the average point of buttock width was $16.39 \mathrm{~cm}$. The average height at the withers of females was $101.48 \mathrm{~cm}$, the average pelvis length was $36.00 \mathrm{~cm}$, and the average pelvis width was $13.66 \mathrm{~cm}$. The obtained data show that the height at the withers influences the pelvis development, and first of all its length and width for both males and females. The Austrian type of donkey, comparatively to the other types in the world, is of the average size.

\section{REFERANCES}

1. Casini, L., Sgorbini, M., Magni, L., Corazza, M., Valutazioni morfologiche nell Asino sorcino crociato dell Amiata. Ipologia Anno., 18, (3): 33-35, 2007.

2. Essert Z., Domaći magarac otoka Mljeta. Veterinaria, 1: 41-54, 1959.

3. Urošević, M., Nemecek, M., Drobnjak, D., Gangl, A., Dameski, P., Stojić, P., Stanišić, G., Morphological characterization of the White Baroque Donkey. Animal Health, Production and Hygiene, 8 (1): 627-633, 2019.

4. Ayad, A., Aissanou, S., Amis, K., Latreche, A., Iguer-Ouada, M., Morphological characteristics of donkeys (Equus asinus) in Kabylie area, Algeria. Slovak J. Anim. Sci., 52 (2): 53-62, 2019.

5. Tsega, A. and Lemma, A., Phenotypic characteristics and sexual behaviour of Sennar jacks (Equus asinus). Ethiopian Veterinary Journal, 19 (1): 11-21, 2015.
UROŠEVIĆ M., et al.

6. Urošević, M., Nemeček, M., Drobnjak, D., Urošević, M.B., Matarugić, D., Stojić, P., Head length and pelvis length ratio in relation to the height of withers in donkey female. Agroznanje, 16, (5): 637-643, 2015.

7. Yilmaz, O., Wilson, T., The domestic livestock resources of Turkey: Notes on donkeys. The Journal of Animal \& Plant Sciences, 23 (2): 651-656, 2013.

8. Ivanković, A., Caput, P., Mioč, B., Pavić, $\mathrm{V}$., The phenotype features of donkeys in Croatia. Agriculture Conspectus Scientificus, 65, (2): 99-105, 2000.

9. Kostukova, M., Černohorska, H., Bihuncova, I., Oravcova, I., Sobotkova, E., Jiskrova, I., Characteristics of morphological parameters of donkeys in the Czech Republic. Acta Universitati sAgricultuae et Silviculturae Mendelianae Brunensis, 63, (2) :419-424, 2015.

10.Beretti, V., Zanon, A., Soffiantini, C.S., Sabbioni, A., Preliminary Results about Morphological and demographic traits of Romagnolo donkey. Ann. Fac. Medic. Vet. di Parma, 25: 131-144, 2005.

11.Shawaf, T., Almathen, F., Al-Ahmad, J., Elmoslemany, A., Morphological characteristics of Hassawi Donkey, Eastern Province, Saudi Arabia. Alexandria Journal of Veterinary Science, 49, (2): 178-183, 2016.

12.Trailović, R., Ivanov, S., Dimitrijević, V., Trailović, D., Some morphological and health characteristics of domestic Balkan Donkey on Staraplanina. Equine Nutrition and Pathology. Horseville, Proceedings, 180-187, 2011.

13.Babić, E., Prilog poznavanju apuljskih magaraca u Dalmaciji. Veterinarski arhiv, 9 (4): 228-252, 1939.

14. Sargentini, C., Tocci, R., Martini, A., Bozzi, R., Morphological characterization of Amiata donkey through Multivariate analyses. Revista Brasileira de Zootecnia, 47: e20170310, 2018. 